\title{
Analysis of some metallic elements and metalloids composition and relationships in parasol mushroom Macrolepiota procera
}

\author{
Jerzy Falandysz ${ }^{1}$ (D) Atindra Sapkota ${ }^{2}$ - Anna Dryżałowska ${ }^{1} \cdot$ Malgorzata Mędyk $^{1}$. \\ Xinbin Feng ${ }^{2}$
}

Received: 20 September 2016 / Accepted: 27 April 2017 / Published online: 17 May 2017

(C) The Author(s) 2017. This article is an open access publication

\begin{abstract}
The aim of the study was to characterise the multielemental composition and associations between a group of 32 elements and 16 rare earth elements collected by mycelium from growing substrates and accumulated in fruiting bodies of Macrolepiota procera from 16 sites from the lowland areas of Poland. The elements were quantified by inductively coupled plasma quadrupole mass spectrometry using validated method. The correlation matrix obtained from a possible $48 \times 16$ data matrix has been used to examine if any association exits between 48 elements in mushrooms foraged from 16 sampling localizations by multivariate approach using principal component (PC) analysis. The model could explain up to $93 \%$ variability by eight factors for which an eigenvalue value was $\geq 1$. Absolute values of the correlation coefficient were above 0.72 (significance at $p<0.05$ ) for 43 elements. From a point of view by consumer, the absolute content of $\mathrm{Cd}, \mathrm{Hg}, \mathrm{Pb}$ in caps of $M$. procera collected from background (unpolluted) areas could be considered elevated while sporadic/occasional ingestion of this mushroom is considered safe. The multivariate functional analysis revealed on associated accumulation of many elements in this mushroom. M. procera seem to possess some features of a bio-indicative species for anthropogenic $\mathrm{Pb}$ but also for some geogenic metals.
\end{abstract}

Responsible editor: Philippe Garrigues

Jerzy Falandysz

jerzy.falandysz@ug.edu.pl

1 Laboratory of Environmental Chemistry \& Ecotoxicology, Gdańsk University, 63 Wita Stwosza Str, 80-308 Gdańsk, Poland

2 State Key Laboratory of Environmental Geochemistry, Institute of Geochemistry, Chinese Academy of Sciences, Guiyang 550002, China
Keywords Foraging · Fungi · Heavy metals · Trace elements $\cdot$ Mushrooms $\cdot$ Poland

\section{Introduction}

Macrolepiota procera (Scop.) Sing., commonly known as Field Parasol, Parasol Mushroom or Shaggy Parasol, is a saprobe. It is edible and widely collected in temperate regions and sub-tropical regions such as India, Thailand, China or Pakistan and across Europe (Kułdo et al. 2014; Melgar et al. 2016; Stefanović et al. 2016a; Širić et al. 2016; Xiaolan 2009). The pileus of $M$. procera are highly valued by locals. This is because of the taste and aroma of the cooked fresh individuals - sautéed, roasted, fried in butter or grilled, roasted with eggs or stuffed and broiled. According to some cooking recipes, the dried caps of $M$. procera could be resoaked in fresh water and both; the flesh and macerate (liquid) can be used for a dish. Frying of $M$. procera with butter or vegetable oil can to some degree result in leakage of elements out of a fleshy cap as was observed for fried Cantharellus cibarius and Boletus edulis and radiocaesium $\left({ }^{137} \mathrm{Cs}\right)$ (Steinhauser and Steinhauser 2016). Nevertheless, caps of $M$. procera before frying are usually surrounded in flour, then in a drooping egg. Hence, any serious leakage of bio- or toxic elements out of a cap (or prepared dish) seems unlikely. Re-soaking of dried caps of M. procera in fresh water can have a more pronounced influence on possible leakage out of minerals but no figures are available. Blanching (parboiling) can decrease content of minerals in cooked mushrooms and also pickling, while a fate of a particular element can be different and highly dependent on its chemical form, localization within cells and type of chemical bonds made (Drewnowska et al. 2017a, 2017b; Falandysz and Drewnowska 2017). 
M. procera prefers lighted and warm places. Especially in calcareous and sandy soils that are well-drained in forests, meadows and gardens (Rizal et al. 2015). In Asia, Macrolepiota species such as M. procera, M. dolichaula (Berk. \& Broome) Pegler \& R.W. Rayner, M. gracilenta (Krombh.) Wasser are consumed by locals (Woźniak 2009). In Europe, $M$. procera is mistaken with the deadly Amanita phalloides (Vaill. ex Fr.) Link., (Death Cap, or Destroying Angel) and Chlorophyllum molybdites (G. Mey.) Massee (False Parasol). Because of its popularity and versatility, it is also cultivated in kitchen gardens. This mushroom, like certain other macromycetes, when found in its natural habitats in background (unpolluted) areas, is efficient in accumulating toxic mercury $(\mathrm{Hg})$, cadmium $(\mathrm{Cd})$, lead $(\mathrm{Pb})$, silver $(\mathrm{Ag})$ and some micronutrients in fruiting bodies (Falandysz et al. 2001, 2003; García et al. 2009; Krasińska and Falandysz, 2016; Gąsecka et al. 2017; Melgar et al. 2009, 2016; Mędyk et al. 2017; Mleczek et al. 2013, 2016a, b, 2017; Saba et al. 2016a, b, c; Sarikurkcu et al. 2015). Due to its bioaccumulating property, many researchers are continuously investigating Macrolepiota species commonly collected by locals for their essential microminerals, macrominerals, metalloids and toxic metals contents in the fruiting bodies (Baptista et al. 2009; Falandysz et al. 2007a; Gucia et al. 2012a, b; Ǩanda et al. 2005).

This study attempts to investigate fruiting bodies of M. procera for its co-occurrence and associations between metallic elements and metalloids such as $\mathrm{Ag}, \mathrm{As}, \mathrm{Ba}, \mathrm{Be}, \mathrm{Bi}$, $\mathrm{Cd}, \mathrm{Co}, \mathrm{Cs}, \mathrm{Cu}, \mathrm{Ga}, \mathrm{Ge}, \mathrm{Hf}, \mathrm{Hg}, \mathrm{In}, \mathrm{Li}, \mathrm{Mo}, \mathrm{Nb}, \mathrm{Ni}, \mathrm{Pb}, \mathrm{Rb}$, $\mathrm{Sb}, \mathrm{Sn}, \mathrm{Sr}, \mathrm{Ta}, \mathrm{Th}, \mathrm{Ti}, \mathrm{Tl}, \mathrm{U}, \mathrm{V}, \mathrm{W}, \mathrm{Zn}, \mathrm{Zr}$ and rare earth elements (Sc, Y, La, Ce, Pr, Nd, Sm, Eu, Gd, Tb, Dy, Ho, $\mathrm{Er}, \mathrm{Tm}, \mathrm{Yb}$ and $\mathrm{Lu}$ ) accumulated in caps and stipes.

\section{Materials and methods}

Fruiting bodies of $M$. procera were collected from 16 different sites from the lowland areas in northern and central regions of Poland: Włocławek - outskirts (forests) (52 $39^{\circ} 33^{\prime \prime} \mathrm{N} 19^{\circ} 04^{\prime}$ $05^{\prime \prime}$ E) [site 1; Fig. 1]; Pomerania, Lębork (54 $33^{\circ} \mathrm{N} 17^{\circ} 45^{\prime}$ E) [site 2]; Warmia land, Olsztyn/Szczytno ( $53^{\circ} 47^{\prime} \mathrm{N} 20^{\circ} 30^{\prime}$ E $/ 53^{\circ} 33^{\prime} 46^{\prime \prime} \mathrm{N} 20^{\circ} 59^{\prime} 7^{\prime \prime}$ E) [3]; Trójmiejski Landscape Park-Gdańsk-Wrzeszcz (54 22' 10.1" N $\left.18^{\circ} 35^{\prime} 47.0^{\prime \prime} \mathrm{E}\right)$ [site 4]; Augustów Primeval Forest $\left(53^{\circ} 87^{\prime} 28^{\prime \prime} 0 \mathrm{~N} 22^{\circ} 97^{\prime}\right.$ $43^{\prime \prime} 0$ E) [site 5]; Tuchola Pinewoods, Łuby ( $53^{\circ} 42^{\prime} 30^{\prime \prime} \mathrm{N} 18^{\circ}$ $22^{\prime} 53^{\prime \prime}$ E) [6]; Wdzydze Landscape Park (54 $00^{\circ} 47^{\prime \prime} \mathrm{N} 17^{\circ}$ $54^{\prime} 04^{\prime \prime}$ E) [7]; Warmia land, Sarnówek (53 39' 33.78" N $19^{\circ}$ $\left.35^{\prime} 16.83^{\prime \prime} \mathrm{E}\right)$ [site 8]; Toruń outskirts (forests) $\left(53^{\circ} 01^{\prime} 20^{\prime \prime}\right.$ N $18^{\circ} 36^{\prime} 40^{\prime \prime}$ E) [site 9]; Vistula River Sand-bar, Stegna (54 $19^{\prime} 35^{\prime \prime} \mathrm{N} 19^{\circ} 6^{\prime} 44^{\prime \prime}$ E) [10]; Nadwarciańska Forest (52 $12^{\prime}$ $00^{\prime \prime} \mathrm{N} 17^{\circ} 54^{\prime} 00^{\prime \prime}$ E) [site 11]; Warmia land, Jeziorak lakeisland of Gierszak (53 $\left.53^{\circ} 43^{\prime} 23.24^{\prime \prime} \mathrm{N} 19^{\circ} 36^{\prime} 46.80^{\prime \prime} \mathrm{E}\right)$ [site 12]; Zielonka near Poznań forests (52 $33^{\prime} 13^{\prime \prime} \mathrm{N} 17^{\circ} 06^{\prime} 49^{\prime \prime}$

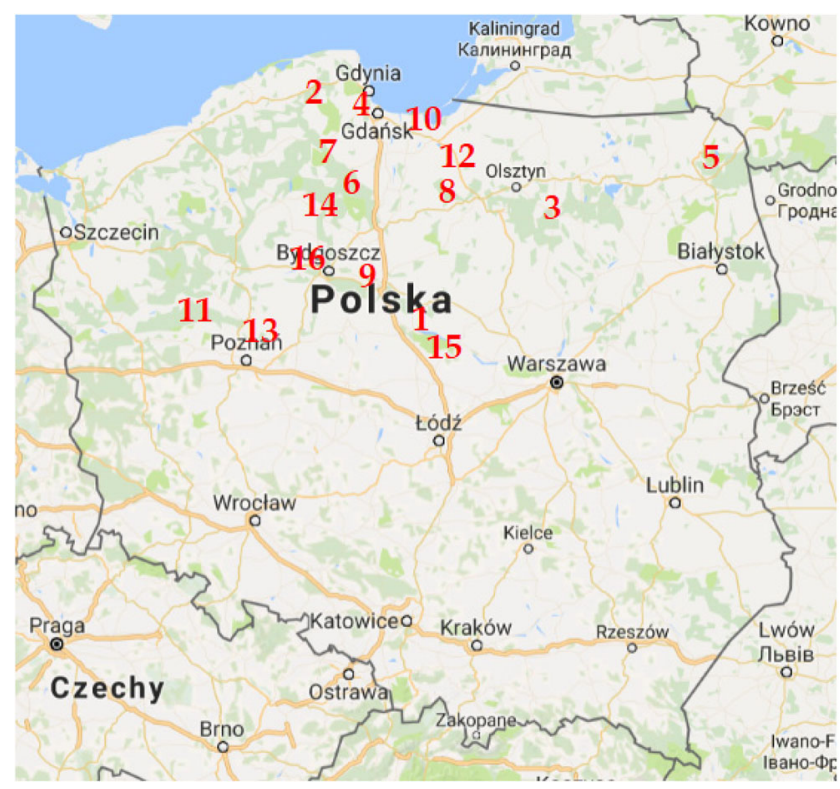

Fig. 1 Sampling sites of M. procera (site 1: Włocławek-outskirts (forests), site 2: Pomerania, Lębork; site 3: Warmia land, Olsztyn/ Szczytno; site 4: Trójmiejski Landscape Park-Gdańsk-Wrzeszcz; site 5: Augustów Primeval Forest; site 6: Tuchola Pinewoods, Łuby; site 7: Wdzydze Landscape Park; site 8: Warmia land, Sarnówek; site 9: Toruń - outskirts (forests); site 10: Vistula River Sand-bar, Stegna; site 11: Nadwarciańska Forest; site 12: Warmia land, Jeziorak lake - island of Gierszak; site 13: Zielonka near Poznań forests; site 14: Tuchola Pinewoods, Osie; site 15: Kukawy/Goreń region and site 16: Bydgoszcz forests; see also Table 1)

E) [site 13]; Tuchola Pinewoods, Osie $\left(53^{\circ} 35^{\prime} 57^{\prime \prime} \mathrm{N} 18^{\circ} 20^{\prime}\right.$ 41" E) [site 14]; Kukawy/Goreń region (52 $33^{\prime} 52^{\prime \prime} \mathrm{N} 19^{\circ} 11^{\prime}$ $42^{\prime \prime} \mathrm{E} / 52^{\circ} 31^{\prime} 50^{\prime \prime} \mathrm{N} 19^{\circ} 17^{\prime} 22^{\prime \prime}$ E) [site 15] and Bydgoszcz forests $\left(53^{\circ} 7^{\prime} \mathrm{N} 18^{\circ} 0^{\prime} \mathrm{E}\right)$ [site 16] (Fig. 1, Table 1). The sites of $M$. procera collection can be considered as background (unpolluted) and without local or regional major emitters of heavy metals in forests of the lowland Poland. A major branch of metallurgy and ore mining industry is localized in the central (iron mill near Warszawa, Fig. 1) and southern regions of Poland (Brzezicha-Cirocka et al. 2016).

Soils at the forested areas of the lowland Poland are podzolic soils which were formed by pine and mixed/pine forests and of mesophilic deciduous and coniferous forests in the zone of warm-temperate climate and are slightly acidic (Degórski 2004). Typical soils there are podzols, pseudopodzols and rusty soils poor in nutrients and developed from fluvioglacial sands with a texture of sands and somewhere in the outskirts of lakes and rivers with peats, peatmuck soils and vertisols. The tree covers are dominated by needle trees such as Pinus sylvestris L. and in lower proportion with Picea abies (L.) H. Karst., Larix decidua Mill., Betula pendula Roth, Betula pubescens Ehrh., Alnus glutinosa (L.) Gaertn., Quercus robur L., Quercus petraea, (Matt.) Liebl., Fagus sylvatica L. (Statistical Office 2014). Each composite sample of caps and whole fruiting bodies consisted of 10 to 30 individuals. 


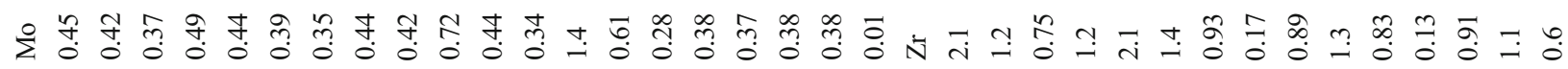
궁

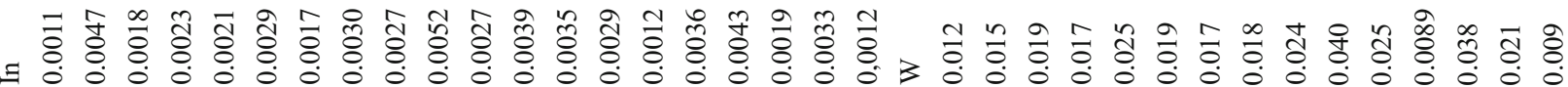

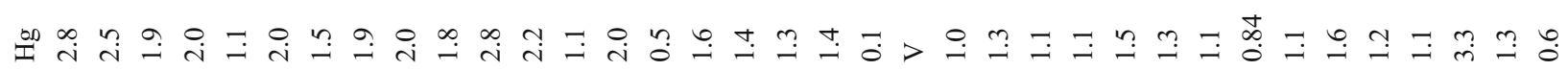

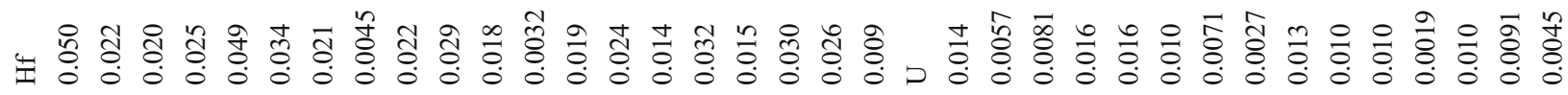

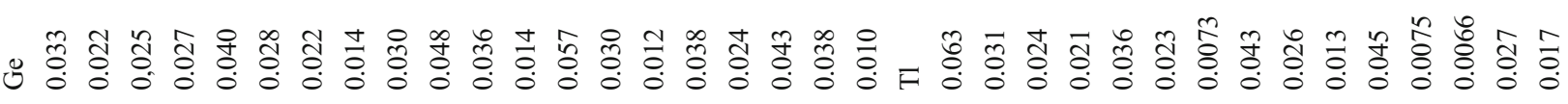

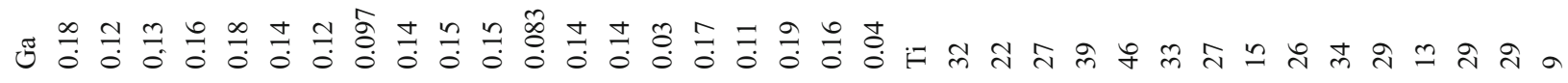

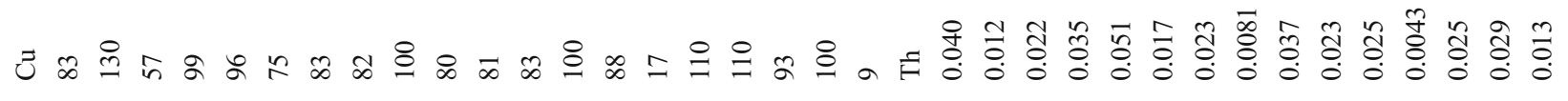

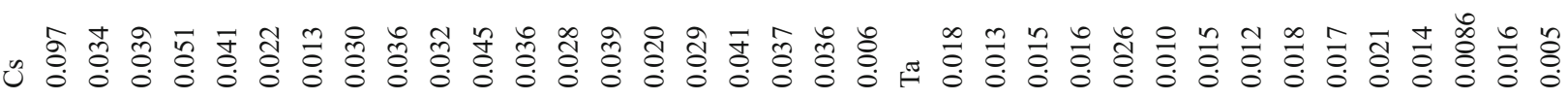

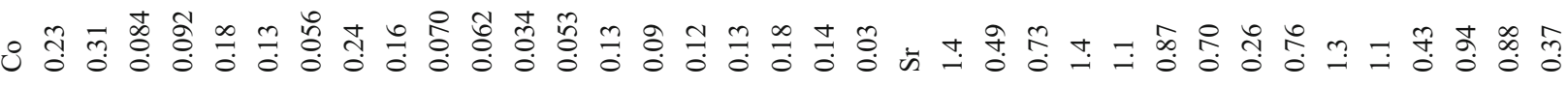
च

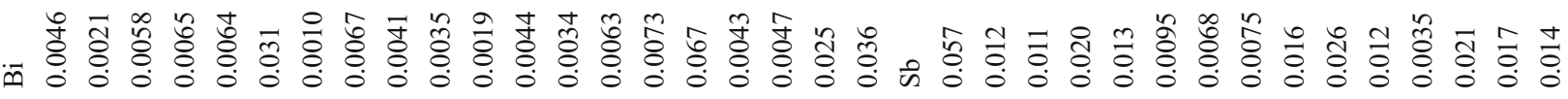
\%

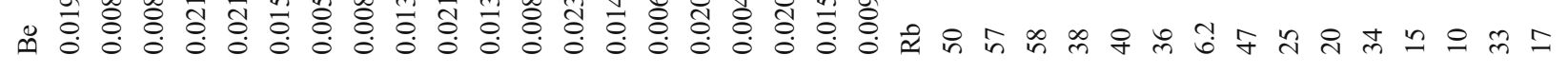
ஜ

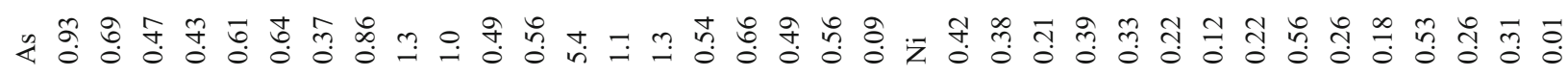
贸

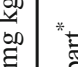

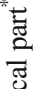
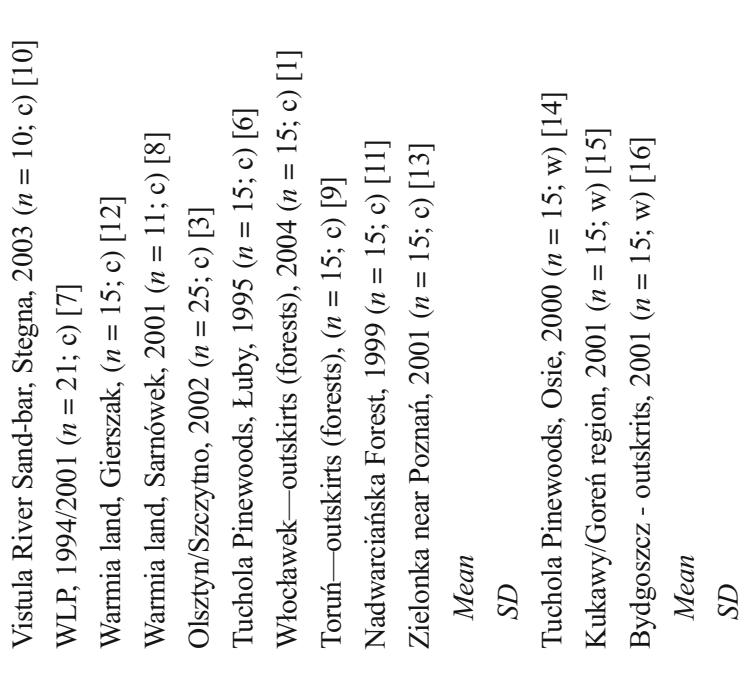
预

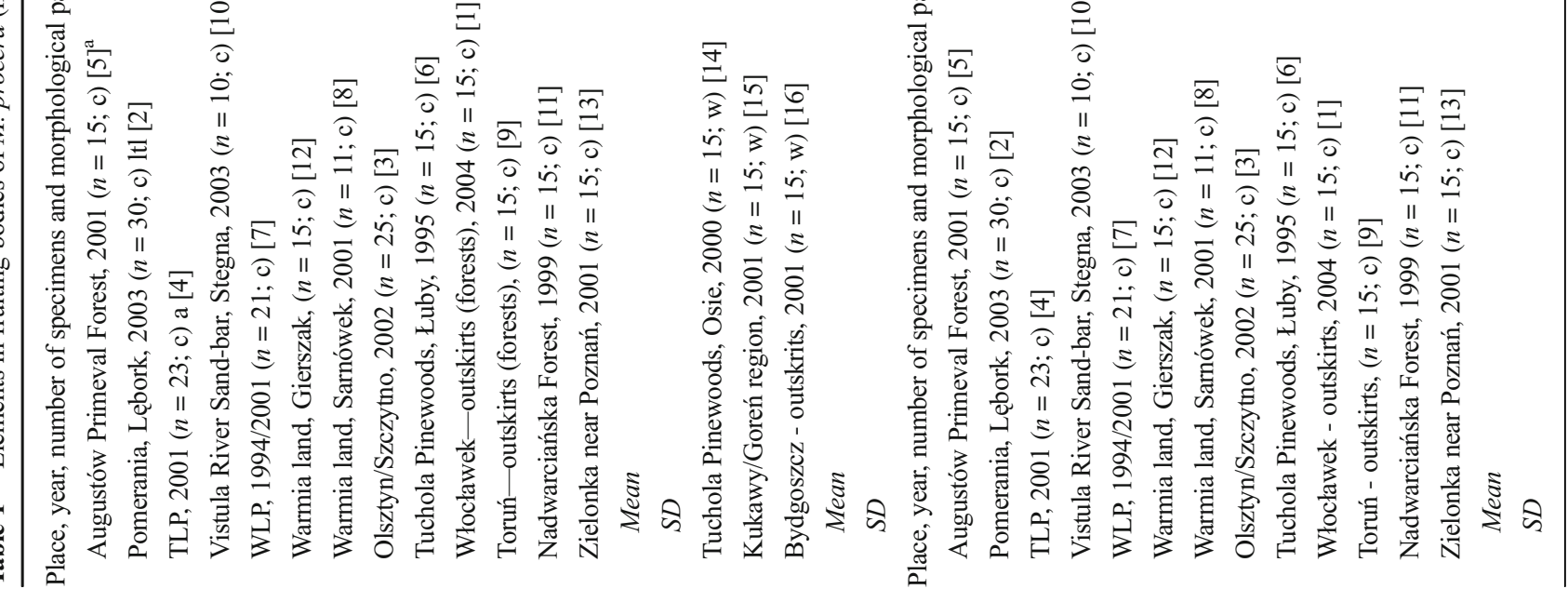


The fungal biomass dehydrated and grounded into a fine powder before analysis was dried at a temperature of $65^{\circ} \mathrm{C}$ for $12 \mathrm{~h}$ and a subsample (about 200-mg samples made in duplicate) was mixed with $3 \mathrm{~mL}$ solution of ultrapure concentrated nitric acid $\left(\mathrm{HNO}_{3}, 65 \%\right.$, ) and $1 \mathrm{~mL}$ of ultrapure hydrofluoric acid (HF) in a polytetrafluoroethylene tubes (PTFE). Then, the tubes were screw tightened in stainless steel jackets and placed in an oven at $150{ }^{\circ} \mathrm{C}$ for $78 \mathrm{~h}$. The solutions obtained were evaporated to dryness at $110^{\circ} \mathrm{C}$, to remove the excess of $\mathrm{HF}$ (Bi et al. 2007). Then, it was dissolved in $1 \mathrm{~mL}$ of $\mathrm{HNO}_{3}$ to make the final volume up to $50 \mathrm{~mL}$, which was then transferred to a sample tube. As an internal standard, rhodium (Rh) $(10-20 \mu \mathrm{g} / \mathrm{L})$ was added to the samples prior to the Quadruple ICM-MS analysis (The Quadrupole-ICP-MS ELAN DRC-e; PerkinElmer, Waltham, MA, USA). In order to achieve good analytical quality control, quality assurance and blanks of certain certified reference materials were examined. Each element was measured three times and the values of relative standard deviation (RSD) were within 5\% in the samples and the certified values for certified reference materials (CRM) (Liang and Grégoire 2000). The CRMs used were citrus leafs (GBW 10020) and soil (GBW 07405) produced by the Institute of Geophysical and Geochemical Exploration, China (Shi et al. 2011).

The computer software Statistica, version 10.0 (Statsoft Polska, Kraków, Poland), was used for statistical analysis of data and for graphical presentation of the results of two dimensional multiple scatter plot relationships between the variables.

\section{Results and discussion}

\section{Toxic metallic elements and metalloids}

Cadmium $(\mathrm{Cd})$, mercury $(\mathrm{Hg})$ and lead $(\mathrm{Pb})$ are common constituents of $M$. procera and they occurred in caps at $2.1 \pm 2.4 \mathrm{mg} \mathrm{kg}^{-1} \mathrm{db}$ (arithmetic mean plus standard deviation) (Cd), $2.0 \pm 0.5 \mathrm{mg} \mathrm{kg}^{-1} \mathrm{db}(\mathrm{Hg})$ and $2.8 \pm 1.4 \mathrm{mg} \mathrm{kg}^{-1} \mathrm{db}$ $(\mathrm{Pb})$ (Table 1). If assume that $\mathrm{Cd}, \mathrm{Hg}$ and $\mathrm{Pb}$ remain in the flesh of caps, when they are sautéed, roasted, fried in butter, grilled or roasted with eggs, a single mushroom dish (100 to $300 \mathrm{~g}$ ) certainly will provide an elevated quantity of each heavy metal $(0.021-0.063 \mathrm{mg}$ of Cd per capita, 0.02 $0.06 \mathrm{mg} \mathrm{Hg}$ per capita and $0.028-0.084 \mathrm{mg} \mathrm{Pb}$ per capita). Hence, frequent eating of caps of $M$. procera could be not recommended. Nevertheless, unknown is the bioaccessibility of $\mathrm{Cd}, \mathrm{Pb}$ and $\mathrm{Hg}$ contained in caps of $\mathrm{M}$. procera for humans.

Contamination with toxic $\mathrm{Cd}$ and $\mathrm{Pb}$ of edible mushrooms is regulated in the European Union but not in the case of $\mathrm{Hg}$, As or any other inorganic contaminant. The maximum limit of Cd established is $0.2 \mathrm{mg} \mathrm{kg}^{-1}$ fresh product $\left(2.0 \mathrm{mg} \mathrm{kg}^{-1}\right.$ in dried product-assuming moisture content is at 90\%) in 
Table 2 Factor loadings (Varimax normalized)

\begin{tabular}{|c|c|c|c|c|c|c|c|c|}
\hline Eigenvalues & 24.25 & 7.26 & 4.06 & 2.31 & 2.14 & 2.10 & 1.40 & 1.05 \\
\hline Total variance $(\%)$ & 50.52 & 15.13 & 8.46 & 4.82 & 4.47 & 4.37 & 2.91 & 2.18 \\
\hline Cumulative $\%$ & 50.52 & 65.65 & 74.11 & 78.94 & 83.40 & 87.77 & 90.68 & 92.86 \\
\hline Variables & $\mathrm{PC} 1$ & PC2 & PC3 & PC4 & PC5 & PC6 & PC7 & PC8 \\
\hline $\mathrm{Li}$ & 0.24 & -0.16 & -0.08 & 0.23 & 0.28 & 0.72 & -0.12 & 0.09 \\
\hline $\mathrm{Be}$ & 0.76 & 0.52 & 0,08 & 0.12 & 0.11 & -0.08 & 0.00 & -0.07 \\
\hline $\mathrm{Sc}$ & 0.58 & -0.08 & 0.18 & 0.08 & 0.25 & -0.65 & -0.07 & 0.00 \\
\hline V & 0.01 & 0.93 & -0.07 & -0.09 & -0.06 & -0.01 & -0.05 & -0.24 \\
\hline $\mathrm{Co}$ & 0.04 & -0.20 & 0.23 & -0.15 & 0.19 & 0.03 & 0.84 & -0.11 \\
\hline $\mathrm{Ni}$ & 0.02 & -0.05 & 0.32 & -0.07 & 0.79 & 0.19 & -0.04 & 0.02 \\
\hline $\mathrm{Cu}$ & 0.08 & 0.15 & -0.07 & -0.58 & 0.52 & 0.15 & 0.24 & -0.37 \\
\hline $\mathrm{Zn}$ & -0.01 & 0.95 & 0.00 & -0.05 & 0.05 & -0.16 & -0.12 & 0.03 \\
\hline $\mathrm{Ga}$ & 0.94 & 0.13 & 0.22 & 0.10 & -0.04 & 0.06 & 0.12 & -0.03 \\
\hline $\mathrm{Ge}$ & 0.63 & 0.74 & -0.01 & 0.01 & -0.11 & 0.10 & -0.03 & 0.13 \\
\hline As & -0.15 & 0.95 & 0.05 & 0.16 & 0.12 & -0.03 & -0.06 & -0.07 \\
\hline $\mathrm{Rb}$ & -0.11 & -0.36 & 0.33 & 0.05 & 0.07 & -0.19 & 0.70 & 0.23 \\
\hline $\mathrm{Sr}$ & 0.92 & 0.08 & 0.14 & -0.11 & -0.07 & -0.03 & -0.19 & -0.02 \\
\hline Y & 0.97 & -0.05 & 0.17 & -0.03 & 0.03 & -0.10 & -0.06 & 0.03 \\
\hline $\mathrm{Zr}$ & 0.80 & 0.10 & 0.23 & 0.01 & -0.10 & 0.02 & 0.37 & -0.18 \\
\hline $\mathrm{Nb}$ & 0.92 & 0.02 & -0.18 & 0.17 & -0.12 & 0.18 & 0.03 & -0.10 \\
\hline Mo & -0.02 & 0.96 & 0.00 & 0.06 & 0.06 & -0.15 & -0.08 & 0.09 \\
\hline $\mathrm{Ag}$ & 0.06 & 0.97 & 0.00 & -0.06 & 0.10 & -0.01 & -0.12 & 0.05 \\
\hline $\mathrm{Cd}$ & 0.29 & -0.12 & 0.87 & 0.01 & 0.18 & -0.15 & 0.19 & -0.10 \\
\hline In & -0.30 & 0.35 & -0.12 & -0.77 & 0.07 & -0.10 & 0.11 & 0.04 \\
\hline $\mathrm{Sn}$ & -0.05 & 0.35 & -0.13 & 0.86 & 0.10 & 0.05 & 0.06 & 0.08 \\
\hline $\mathrm{Sb}$ & 0.44 & 0.24 & 0.81 & -0.13 & -0.06 & -0.06 & 0.11 & 0.07 \\
\hline Cs & 0.26 & -0.08 & 0.93 & 0.00 & 0.08 & 0.01 & 0.13 & 0.13 \\
\hline $\mathrm{Ba}$ & 0.80 & -0.13 & 0.20 & 0.02 & 0.31 & -0.27 & -0.19 & 0.04 \\
\hline $\mathrm{La}$ & 0.92 & -0.01 & 0.26 & -0.04 & 0.00 & 0.21 & 0.08 & -0.15 \\
\hline $\mathrm{Ce}$ & 0.92 & -0.03 & 0.19 & -0.02 & 0.01 & 0.25 & 0.09 & -0.19 \\
\hline $\operatorname{Pr}$ & 0.92 & -0.03 & 0.22 & -0.03 & 0.01 & 0.23 & 0.04 & -0.18 \\
\hline $\mathrm{Nd}$ & 0.94 & -0.04 & 0.15 & 0.03 & 0.06 & 0.22 & 0.01 & -0.15 \\
\hline $\mathrm{Sm}$ & 0.97 & -0.10 & 0.10 & 0.05 & 0.02 & 0.16 & 0.03 & -0.07 \\
\hline $\mathrm{Eu}$ & 0.93 & 0.15 & 0.12 & -0.07 & -0.15 & 0.11 & -0.01 & -0.12 \\
\hline Gd & 0.95 & -0.12 & 0.19 & 0.04 & 0.09 & 0.15 & 0.04 & -0.01 \\
\hline $\mathrm{Tb}$ & 0.96 & -0.07 & 0.19 & 0.03 & 0.06 & -0.02 & 0.00 & -0.02 \\
\hline Dy & 0.95 & -0.08 & 0.22 & 0.06 & 0.09 & -0.03 & -0.10 & 0.01 \\
\hline Но & 0.97 & -0.03 & 0.14 & -0.05 & 0.00 & -0.10 & -0.06 & 0.05 \\
\hline $\mathrm{Er}$ & 0.98 & 0.03 & 0.08 & -0.04 & -0.01 & -0.11 & -0.05 & 0.09 \\
\hline $\mathrm{Tm}$ & 0.93 & 0.25 & 0.08 & -0.05 & -0.03 & -0.17 & -0.01 & 0.11 \\
\hline $\mathrm{Yb}$ & 0.97 & 0.06 & 0.07 & -0.10 & -0.07 & -0.13 & -0.04 & 0.08 \\
\hline $\mathrm{Lu}$ & 0.96 & 0.11 & -0.01 & -0.05 & -0.06 & -0.09 & 0.01 & 0.20 \\
\hline Hf & 0.78 & 0.06 & 0.27 & 0.12 & -0.12 & 0.03 & 0.37 & -0.13 \\
\hline $\mathrm{Ta}$ & 0.50 & -0.33 & 0.19 & -0.11 & -0.06 & 0.62 & 0.04 & 0.08 \\
\hline W & 0.37 & 0.77 & -0.12 & -0.03 & -0.24 & 0.19 & 0.05 & 0.32 \\
\hline $\mathrm{Tl}$ & 0.15 & -0.28 & 0.66 & 0.04 & -0.12 & 0.20 & 0.52 & 0.07 \\
\hline $\mathrm{Pb}$ & 0.51 & 0.12 & 0.73 & 0.10 & 0.27 & 0.02 & -0.01 & 0.09 \\
\hline $\mathrm{Bi}$ & 0.33 & -0.07 & -0.19 & -0.12 & -0.13 & -0.12 & -0.03 & -0.76 \\
\hline Th & 0.87 & 0.05 & 0.13 & 0.25 & 0.13 & 0.30 & 0.05 & -0.01 \\
\hline $\mathrm{U}$ & 0.93 & 0.07 & 0.08 & 0.21 & 0.20 & 0.07 & 0.00 & 0.00 \\
\hline $\mathrm{Ti}$ & 0.90 & 0.09 & -0.07 & 0.05 & -0.07 & -0.01 & 0.08 & -0.21 \\
\hline $\mathrm{Hg}$ & -0.06 & 0.16 & -0.02 & 0.06 & 0.89 & -0.13 & 0.18 & 0.13 \\
\hline
\end{tabular}

In italics are the significant loadings used for each principal component

farmed Agaricus bisporus (J.E.Lange) Imbach, Pleurotus ostreatus (Jacq.) P. Kumm. and Lentinula edodes (Berk.) Pegler. This limit for $\mathrm{Cd}$ is $1.0 \mathrm{mg} \mathrm{kg}{ }^{-1}$ fresh product (10 mg kg ${ }^{-1}$ in dried product) for other fungi (EC, 2006, 2008). In the case of $\mathrm{Pb}$ and cultivated mushrooms mentioned, the maximum allowed limit is $0.3 \mathrm{mg} \mathrm{kg}$-1 fresh product (3.0 mg kg dried product) (EC, 2006, 2008). M. procera in this study showed at the average on little contamination with
$\mathrm{Cd}$, i.e., in caps, concentration levels were well below $10 \mathrm{mg} \mathrm{kg}^{-1}$ dried product (Table 1). An exception were individuals collected from the Augustowska Primeval Forest site which contained $\mathrm{Cd}$ in caps at $9.4 \mathrm{mg} \mathrm{kg}^{-1}$ dry biomass (Table 1). The Augustowska Primeval Forest region is considered as pristine (green lungs) and localized faraway of major emitters of heavy metals. A possible explanation for elevated concentration level of $\mathrm{Cd}$ in mushrooms can be because of a 
Fig. 2 Principal component analysis of the trace metallic elements, metalloids and rare earth elements associations in $M$. procera mushroom $(\mathbf{a}-\mathbf{c})$ in the panorama of the Varimax normalized matrices

specific geochemistry of a soil parent material there, but this was not studied.

M. procera from the five sites contained $\mathrm{Pb}$ in caps at concentration level in the range of $3.3-6.1 \mathrm{mg} \mathrm{kg}^{-1}$ dry product (Table 1), which exceeded a limit set for farmed mushrooms mentioned earlier. Maximum contamination with $\mathrm{Pb}$ was similar to $\mathrm{Cd}$ in mushrooms from the Augustowska Primaeval Forest.

Also, silver (Ag) occurred in caps of $M$. procera at content comparable to what was observed for $\mathrm{Cd}, \mathrm{Hg}, \mathrm{Pb}$, i.e., at $1.9 \pm 2.0 \mathrm{mg} \mathrm{kg}^{-1} \mathrm{db}$. An intake of Ag per capita could be similar as is for $\mathrm{Cd}, \mathrm{Hg}$ and $\mathrm{Pb}$. Silver, like $\mathrm{Cd}, \mathrm{Hg}$ and other chalcophile elements, has affinity to sulphur. The elements Ag, $\mathrm{Cd}$ and $\mathrm{Hg}$ are well bio-concentrated by M. procera and several other mushrooms (Chudzyński et al. 2011; Falandysz et al. 1994; Stefanović et al. 2016a, 2016b). Arsenic (As) was in caps at $1.1 \pm 1.3 \mathrm{mg} \mathrm{kg}^{-1} \mathrm{db}$ (Table 1 ), which was at relatively low concentration level while compounds of As were not studied. The inorganic compounds of As are most toxic while much less or almost non-toxic are considered organic arsenic compounds - they can be found in various (species-specific) proportion in mushrooms but can be well accumulated by fungi from a soil polluted with As (Falandysz and Rizal 2016; Falandysz et al. 2017a). There is no other data available on As in M. procera from background areas of Poland.

Available data on antimony ( $\mathrm{Sb}$ ) and thallium ( $\mathrm{Tl})$ in M. procera are scarce (Falandysz et al. 2001). In this study, $\mathrm{Sb}$ was in caps of $M$. procera at $0.017 \pm 0.014 \mathrm{mg} \mathrm{kg}^{-1} \mathrm{db}$ and $\mathrm{Tl}$ at $0.027 \pm 0.017 \mathrm{mg} \mathrm{kg}^{-1} \mathrm{db}$, which are negligible quantities if compared to other toxic chalcophile elements mentioned earlier. In a view of the human consumer, there is a deficit of information on a possible absorption rate of a particular metallic elements and metalloids contained in cooked caps of this mushroom, when ingested. For example, the bioavailability of $\mathrm{Cd}$ from the blanched or pickled mushroom Cantharellus cibarius is considered to be not greater than $20 \%$ (unpublished, JF).

Other elements determined can be considered largely as natural compounds absorbed from the geochemical background that occurred at typical but not elevated concentration levels in M. procera. For example, the chalcophile elements determined such as gallium (Ga), germanium $(\mathrm{Ge})$, indium (In), tin ( $\mathrm{Sn}$ ) and bismuth (Bi) were at the small contents in caps. They contained them (in $\mathrm{mg} \mathrm{kg}^{-1} \mathrm{db}$ ), respectively, at $0.14 \pm 0.03(\mathrm{Ga}), 0.030 \pm 0.012(\mathrm{Ge}), 0.0029 \pm 0.0012$ (In), $0.19 \pm 0.07(\mathrm{Sn})$ and $0.0063 \pm 0.0076(\mathrm{Bi})$. A chalcophile copper $(\mathrm{Cu})$ and zinc $(\mathrm{Zn})$ were both the major trace elements in caps, which contained $\mathrm{Cu}$ at $88 \pm 17 \mathrm{mg} \mathrm{kg}^{-1} \mathrm{db}$ and $\mathrm{Zn}$ at $69 \pm 26 \mathrm{mg} \mathrm{kg}^{-1} \mathrm{db}$ (Table 1). Copper and zinc tend to (a)

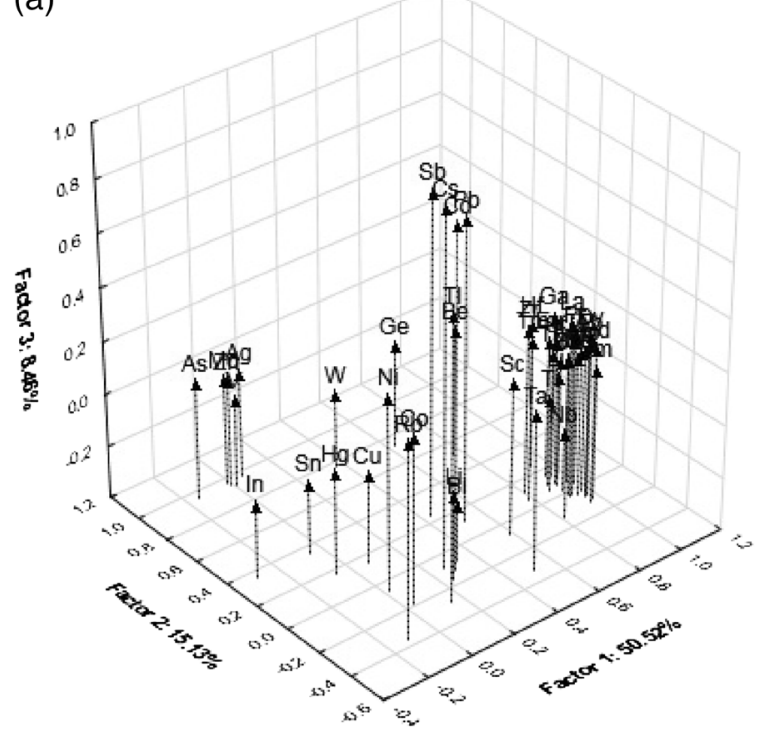

(b)

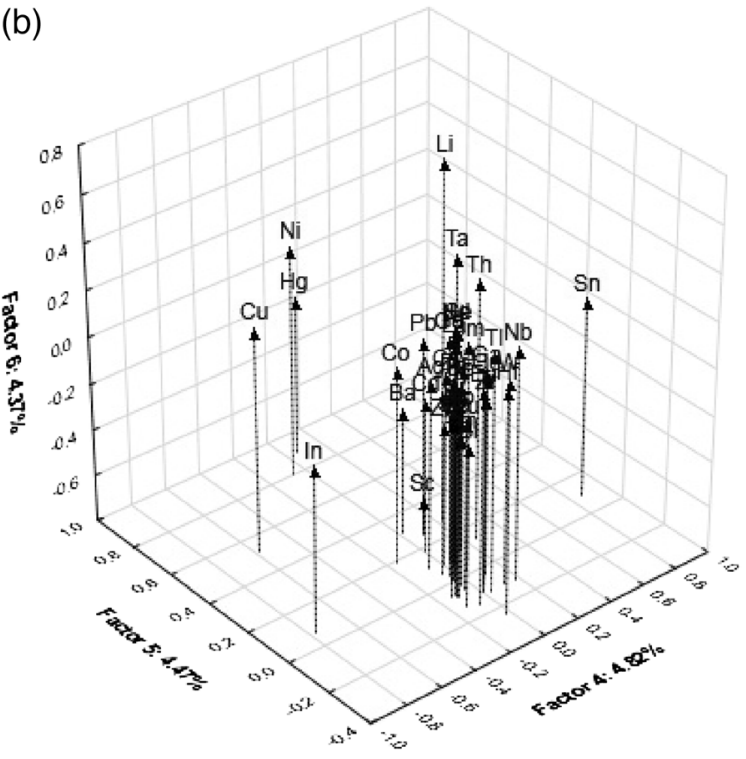

(c)

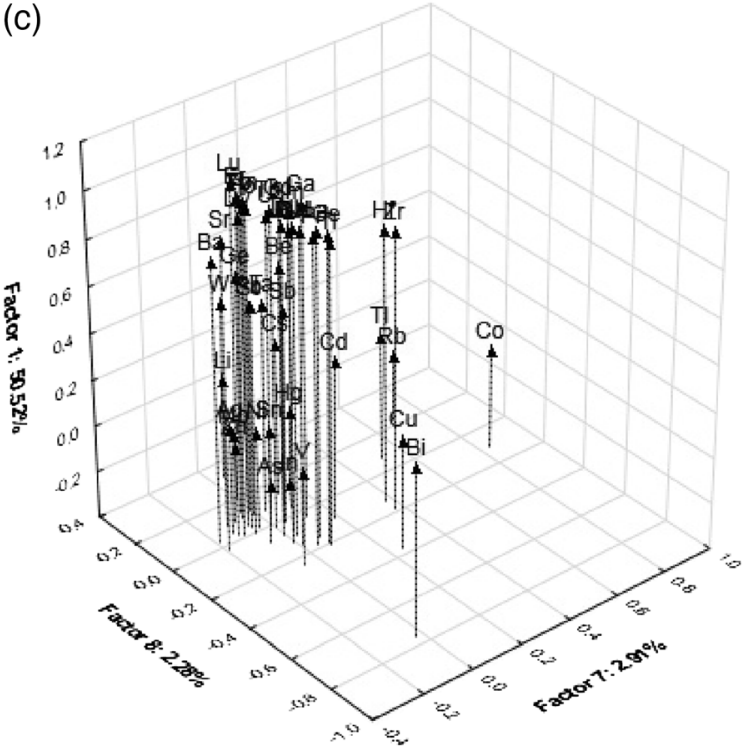


Fig. 3 Principal component analysis of the trace metallic elements, metalloids and rare earth elements associations in its sampling localizations (a-c) of M. procera in the panorama of the Varimax normalized matrices

accumulate similarly in the hymenophore and the rest of the fruiting body of $M$. procera (Alonso et al. 2003). Regardless of the contents of toxic elements such as $\mathrm{Cd}, \mathrm{Pb}$ and $\mathrm{Hg}$, the caps of M. procera seem a good source of $\mathrm{Cu}$ and $\mathrm{Zn}$.

The alkali metals such as lithium $(\mathrm{Li})$, rubidium $(\mathrm{Rb})$ and caesium $(\mathrm{Cs})$ were in caps at $0.62 \pm 0.85 \mathrm{mg} \mathrm{kg}^{-1} \mathrm{db}(\mathrm{Li})$, $33 \pm 17 \mathrm{mg} \mathrm{kg}^{-1} \mathrm{db}(\mathrm{Rb})$ and $0.039 \pm 0.020 \mathrm{mg} \mathrm{kg}^{-1} \mathrm{db}(\mathrm{Cs})$. For lithium there was a wide span of values for the sites and range from 0.012 to $2.7 \mathrm{mg} \mathrm{kg}^{-1} \mathrm{db}$ (Table 1). There is no other data published on the element $\mathrm{Li}$ in M. procera to confirm observation from this study. Both $\mathrm{Rb}$ and $\mathrm{Cs}$ (stable ${ }^{133} \mathrm{Cs}$ ) were at a small content in $M$. procera, while much richer in both elements are mycorrhizal mushrooms (Falandysz and Borovička 2013). A low status of stable ${ }^{133} \mathrm{Cs}$ (and also $\mathrm{Rb}$ ) in fruiting bodies of $M$. procera, when related to certain other mushrooms, seem to explain a low susceptibility of this mushroom for contamination with radioactive caesium $\left({ }^{134 / 137} \mathrm{Cs}\right)$.

The alkali earth metals such as beryllium (Be), strontium $(\mathrm{Sr})$ and barium $(\mathrm{Ba})$ highly differed in their content in $M$. procera. The element $\mathrm{Be}$ occurred in caps at $0.014 \pm 0.006 \mathrm{mg} \mathrm{kg}^{-1} \mathrm{db}$, the $\mathrm{Sr}$ was at $0.88 \pm 0.37 \mathrm{mg} \mathrm{kg}^{-1}$ $\mathrm{db}$ and the $\mathrm{Ba}$ was at $3.9 \pm 2.4 \mathrm{mg} \mathrm{kg}^{-1} \mathrm{db}$. Data on $\mathrm{Ba}$ in M. procera provided in this study (Table 1 ) showed on a greater content, when compared to results for $M$. procera obtained by argon plasma atomic emission spectroscopy (Ouzouni and Riganakos 2007).

Other elements for which are available a few sets of data on their occurrence and accumulation by fungi in fruiting bodies are cobalt $(\mathrm{Co})$, nickel $(\mathrm{Ni})$, thorium (Th), titanium (Ti), uranium (U) and vanadium (V) (Aloupi et al. 2011; Baumann et al. 2014; Borovicka et al. 2011; Falandysz et al. 2007b; Vetter and Siller 1997; Řanda et al. 2005). Among mushrooms that were studied so far, the Fly Agaric Amanita muscaria (L.) Lam. was identified as the specific accumulator of vanadium, while not one specifically efficiently accumulated $\mathrm{Co}, \mathrm{Ni}, \mathrm{Th}$, $\mathrm{Ti}$ or U. The caps of $M$. procera contained Co at $0.13 \pm 0.09 \mathrm{mg} \mathrm{kg}^{-1} \mathrm{db}$, Ni at $0.31 \pm 0.01 \mathrm{mg} \mathrm{kg}^{-1} \mathrm{db}$, Th at $0.029 \pm 0.013 \mathrm{mg} \mathrm{kg}^{-1} \mathrm{db}, \mathrm{U}$ at $0.0091 \pm 0.0045 \mathrm{mg} \mathrm{kg}^{-1} \mathrm{db}$, Ti at $29 \pm 9 \mathrm{mg} \mathrm{kg}^{-1} \mathrm{db}$, and $\mathrm{V}$ at $1.3 \pm 0.6 \mathrm{mg} \mathrm{kg}^{-1} \mathrm{db}$.

The obtained results for elements such as hafnium (Hf), which occurred in caps at $0.024 \pm 0.014 \mathrm{mg} \mathrm{kg}^{-1} \mathrm{db}$, tantalum (Ta) at $0.016 \pm 0.005 \mathrm{mg} \mathrm{kg}^{-1} \mathrm{db}$ and wolfram (W) at $0.021 \pm 0.009 \mathrm{mg} \mathrm{kg}^{-1} \mathrm{db}$. They all agree with a single result obtained for a whole fruiting body of $M$. procera from the Czech Republic and obtained by neutron activation analysis (Řanda and Kučera 2004). (a)
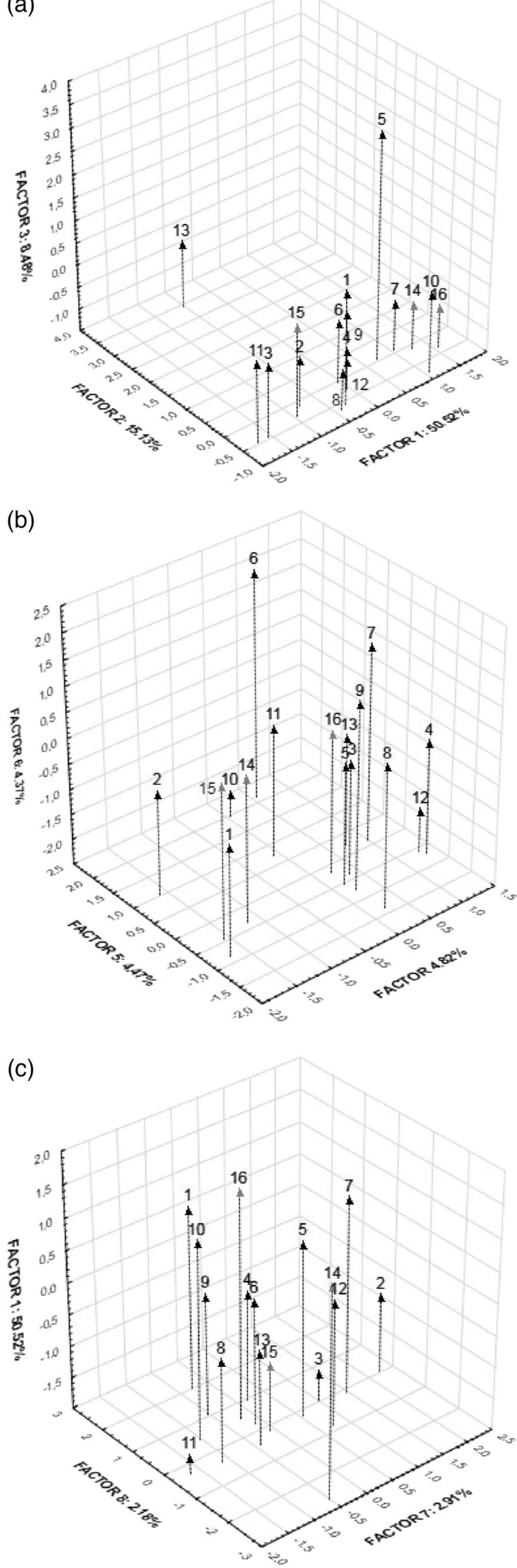
Absent in the available literature are data on occurrence in $M$. procera of the metallic elements such as molybdenum (Mo), niobium $(\mathrm{Nb})$ and zirconium $(\mathrm{Zr})$. Those elements occurred in caps at $0.61 \pm 0.28 \mathrm{mg} \mathrm{kg}^{-1} \mathrm{db}$ (Mo), $0.051 \pm 0.023 \mathrm{mg} \mathrm{kg}^{-1} \mathrm{db}(\mathrm{Nb})$ and $1.1 \pm 0.6 \mathrm{mg} \mathrm{kg}^{-1} \mathrm{db}$ (Zr) (Table 1).

\section{Multivariate analysis of data}

A possible relationship between 48 metallic elements (including data on rare earth elements) (Falandysz et al. 2017b) and metalloids accumulated in caps and whole fruiting bodies by fungus $M$. procera collected at 16 spatially distributed places in the northern and central regions of Poland has been examined using the principal component (PC) analysis (Wyrzykowska et al. 2001). In this multivariate approach, the results from examination of possible $48 \times 16$ data matrix are summarised in Table 2 (results for $48 \times 13$ data matrix obtained separately for caps are not shown). This was possible to explain up to $93 \%$ variability in the $48 \times 16$ data matrix by eight factors as well as up to $96 \%$ variability in the $48 \times 13$ data matrix by eight factors for which an eigenvalue value was $\geq 1$. Absolute values of the correlation coefficient were above 0.72 (significance at $p<0.05$ ) for 43 elements in the $48 \times 16$ data matrix and above 0.70 for 42 elements in the $48 \times 13$ data matrix.

The PC1 was under influence by variables associated with positively correlated $\mathrm{Ba}, \mathrm{Be}, \mathrm{Ce}, \mathrm{Dy}, \mathrm{Er}, \mathrm{Eu}, \mathrm{Ga}, \mathrm{Gd}$, Hf, Ho, La, Lu, Nb, Nd, Pr, Sm, Sr, Tb, Th, Ti, Tm, U, Y, $\mathrm{Yb}$ and $\mathrm{Zr}$, which are largely the lithophile elements that are characterised by similar chemical properties-alkaline earth metals ( $\mathrm{Be}, \mathrm{Ba}, \mathrm{Sr}$ ), which, together with $\mathrm{Mg}$ and $\mathrm{Ca}$, have all a somewhat similar chemical and physical properties (Tabouret et al. 2010). The $\mathrm{Be}, \mathrm{Ba}$ and $\mathrm{Sr}$ are more or less alike to $\mathrm{Ca}$ in the environment and biological systems and $\mathrm{Sr}$ can displace $\mathrm{Ca}$. In the $\mathrm{PC} 1$ associations, positively correlated were also the rare earth elements (RREs) which are similar to $\mathrm{Ca}$ and all have similar chemical and physical properties and tend to exist together. The PC1 was also under the influence by variables associated with positively correlated some other elements ( $\mathrm{Y}, \mathrm{Zr}, \mathrm{Nb}$, $\mathrm{U}, \mathrm{Th}, \mathrm{Ti})$ and also Ga. The PC2 was under the influence by positively correlated Ag, As, Ge, Mo, V, W and Zn, and PC 3 by variables with positively correlated $\mathrm{Cd}, \mathrm{Cs}, \mathrm{Pb}$ and $\mathrm{Sb}$. The PC4 was influenced by variables associated with negatively correlated element indium (In) and positively correlated Sn, the PC5 was with positively correlated $\mathrm{Ni}$ and $\mathrm{Hg}$, the PC6 was with $\mathrm{Li}$, the PC7 was with $\mathrm{Co}$ and the PC8 with negatively correlated Bi (Table 2). The associations among the elements determined and places of mushroom collection in the factor space as a PCA are presented graphically in Figs. 1 and 2.
M. procera as a decomposer absorbs inorganic compounds from a digested decaying plant matter in soils and from the soil solution. Hence, a significant difference in content of the particular element in mushroom between the sampling localization could be largely associated with geochemistry of the soil parent material and content of a particular element and their availability or co-absorption, composition of decaying plant matter and anthropogenic pollution.

The localization Trzebiesza near Poznań — no. 13 on a map (associated with PC2) was separated due to significantly elevated content of Ag, As, Mo, V and $\mathrm{Zn}$ in M. procera (Figs 1a and Fig. 2a). Contrary, the localization Sarnówek in a forested and agricultural region of the Warmia land - no. 8 on a map (associated with PC 3) was separated due to small content of $\mathrm{Cd}, \mathrm{Cs}, \mathrm{Pb}$ and $\mathrm{Sb}$ in mushrooms (Fig. 2a and Fig. 3a). The localization of the Augustów Primeval Forest-no. 5 (associated with PC3) was characterised by elevated content of $\mathrm{Cd}$, $\mathrm{Pb}$ and $\mathrm{Sb}$, which could be related to known a deep in the ground deposits of some metal ores there. This localization was also associated with PC4 by small content of Sn and in mushrooms.

For the localization near Łuby in the Tuchola Pinewoods (no. 6) was strong relationship between $\mathrm{Hg}$ and $\mathrm{Ni}$ (associated with PC 5). The localization of Kościerzyna (no. 7) because of Li (PC6); the localization Lębork (no. 2), because of Co (associated with PC7), and the localization Island Gierszak (no. 12) because of Bi (associated with PC8) (Figs 1 and 2, Table 2).

\section{Conclusion}

M. procera foraged from the background areas could be characterised by elevated content of toxic $\mathrm{Cd}, \mathrm{Hg}$ and $\mathrm{Pb}$ in edible caps of the fruiting bodies while less of As, which is a species-specific feature. Since caps of $M$. procera are cooked without blanching, which could, to some degree, reduce the content of $\mathrm{As}, \mathrm{Cd}, \mathrm{Hg}$ and $\mathrm{Pb}$, a frequent eating of this mushroom may be not desired. Also, toxic $\mathrm{Sb}$ and $\mathrm{Tl}$ were in $M$. procera at small but probably typical concentrations. $M$. procera seem to possess some features of a bio-indicative species for anthropogenic $\mathrm{Pb}$ but also for some geogenic metallic elements. The bio-elements $\mathrm{Cu}$ and $\mathrm{Zn}$ but also several other elements were in $M$. procera in a narrow range of concentration levels that can be explained by a lack of major environmental problems with heavy metals in the regions examined.

Open Access This article is distributed under the terms of the Creative Commons Attribution 4.0 International License (http:// creativecommons.org/licenses/by/4.0/), which permits unrestricted use, distribution, and reproduction in any medium, provided you give appropriate credit to the original author(s) and the source, provide a link to the Creative Commons license, and indicate if changes were made. 


\section{References}

Alonso J, Garcia MÁ, Pérez-López M, Melgar MJ (2003) The concentrations and bioconcentration factors of copper and zinc in edible mushrooms. Arch Environ Contam Toxicol 44:180-188

Aloupi M, Koutrotsios G, Koulousaris M, Kalogeropoulos N (2011) Trace metal contents in wild edible mushrooms growing on serpentine and volcanic soils on the island of Lesvos, Greece. Ecotox Environ Saf 78:184-194

Baptista P, Ferreira S, Soares E, Coelho V, de Lourdes BM (2009) Tolerance and stress response of Macrolepiota procera to nickel. J Agric Food Chem 57:7145-7152

Baumann N, Arnold T, Haferburg G (2014) Uranium contents in plants and mushrooms grown on a uranium-contaminated site near Ronneburg in Eastern Thuringia/Germany. Env Sci Poll Res 21:6921-6929

Bi X, Feng X, Yang Y, Li X, Sin GP, Qiu G, Qian X, Li F, He T, Li P, Liu T, Fu Z (2007) Heavy metals in an impacted wetland system: a typical case from southwestern China. Sci Total Environ 387:257-268

Borovicka J, Kubrova J, Rohovec J, Řanda Z, Dunn CE (2011) Uranium, thorium and rare earth elements in macrofungi: what are the genuine concentrations? Biometals 24:837-845

Brzezicha-Cirocka J, Mędyk M, Falandysz J, Szefer P (2016) Bio- and toxic elements in edible wild mushrooms from two regions of potentially different environmental conditions in eastern Poland. Environ Sci Pollut Res 23:21517-21522

Chudzyński K, Jarzyńska G, Stefańska A, Falandysz J (2011) Mercury content and bio-concentration potential of Slippery Jack, Suillus luteus, mushroom. Food Chem 125:986-990

Degórski M (2004) Regional differences of podzolic soil properties in central and northern Europe. Roczn Gleb 55:59-70

Drewnowska M, Falandysz J, Chudzińska M, Hanć A, Saba M, Barałkiewicz D (2017a) Leaching of arsenic and sixteen metallic elements from Amanita fulva mushrooms after food processing. LWT - Food Sci Technol. doi:10.1016/j.lwt.2017.04.066

Drewnowska M, Hanć A, Barałkiewicz D, Falandysz J (2017b) Pickling of chanterelle Cantharellus cibarius mushrooms highly reduce cadmium contamination. Environ Sci Poll Res: submitted

Falandysz J, Borovička J (2013) Macro and trace mineral constituents and radionuclides in mushrooms: health benefits and risks. Appl Microbiol Biotechnol 97:477-501

Falandysz J, Drewnowska M (2017) Cooking can decrease mercury contamination of a mushroom meal: Cantharellus cibarius and Amanita fulva. Environ Sci Poll Res 24. doi:10.1007/s11356-017-8933-5

Falandysz J, Rizal LM (2016) Arsenic and its compounds in mushrooms: a review. J Environ Sci Health C 34:217-232

Falandysz J, Bona H, Danisiewicz D (1994) Silver content of wild-grown mushrooms from northern Poland. Zeitschr Lebensm Unters Forsch 199:222-224

Falandysz J, Szymczyk K, Ichihashi H, Bielawski L, Gucia M, Frankowska A, Yamasaki S-I (2001) ICP/MS and ICP/AES elemental analysis (38 elements) of edible wild mushrooms growing in Poland. Food Addit Contam 18:503-513

Falandysz J, Lipka K, Kawano M, Brzostowski A, Dadej M, Jędrusiak A, Puzyn T (2003) Mercury content and its bioconcentration factors at Łukta and Morag, Northeastern Poland. J Agric Food Chem 51: 2832-2836

Falandysz J, Gucia M, Mazur A (2007a) Content and bioconcentration factors of mercury by Parasol Mushroom Macrolepiota procera. J Environ Sci Health Part A 42:735-740

Falandysz J, Kunito T, Kubota R, Lipka K, Mazur A, Falandysz JJ, Tanabe S (2007b) Selected elements in Fly Agaric Amanita muscaria. J Environ Sci Health Part A 42:1615-1623

Falandysz J, Zhang J, Wiejak A, Barałkiewicz D, Hanć A (2017a) Metallic elements and metalloids in Boletus luridus, B. magnificus and B. tomentipes mushrooms from polymetallic soils from SW China. Ecotox Environ Saf 142:497-502

Falandysz J, Sapkota A, Meedyk M, Feng X (2017b) Rare earth elements in parasol mushroom Macrolepiota procera. Food Chem 221:24-28

García MA, Alonso J, Melgar MJ (2009) Lead in edible mushrooms levels and bioaccumulation factors. J Hazard Mat 167:777-783

Gąsecka M, Rzymski P, Mleczek M, Siwulski M, Budzyńska S, Magdziak Z, Niedzielski P, Sobieralski K (2017) The relationship between metal composition, phenolic acid and flavonoid content in Imleria badia from non-polluted and polluted areas. J Environ Sci Health Part B 52:171-177

Gucia M, Kojta AK, Jarzyńska G, Rafał E, Roszak M, Osiej I, Falandysz J (2012a) Multivariate analysis of mineral constituents of edible Parasol Mushroom (Macrolepiota procera) and soils beneath fruiting bodies collected from Northern Poland. Environ Sci Poll Res 19:416-431

Gucia M, Jarzyńska G, Kojta AK, Falandysz J (2012b) Temporal variability in twenty chemical elements content of Parasol Mushroom (Macrolepiota procera) collected from two sites over a few years. J Environ Sci Health Part B 47:81-88

Krasińska G, Falandysz J (2016) Mercury in Orange Birch Bolete Leccinum versipelle and soil substratum: bio-concentration by mushroom and probable dietary intake by consumers. Environ Sci Poll Res 23:860-869

Kułdo E, Jarzyńska G, Gucia M (2014) Mineral constituents of edible parasol mushroom Macrolepiota procera (Scop. Ex Fr.) Sing and soils beneath its fruiting bodies collected from a rural forest area. Chem Papers 68:484-492

Liang Q, Grégoire DC (2000) Determination of trace elements in twenty six Chinese geochemistry reference materials by inductively coupled plasma-mass spectrometry. Geostand Newslett 24:51-63

Mędyk M, Chudzińska M, Barałkiewicz D, Falandysz J (2017) Specific accumulation of cadmium and other trace elements in Sarcodon imbricatus using ICP-MS with a chemometric approach. J Environ Sci Health Part B 52:361-366

Melgar MJ, Alonso J, Garcia M (2009) Mercury in edible mushrooms and soil. Bioconcentration factors and toxicological risk. Sci Total Environ 407:5328-5334

Melgar MJ, Alonso J, García MA (2016) Cadmium in edible mushrooms from NW Spain: Bioconcentration factors and consumer health implications. Food Chem Toxicol 88:13-20

Mleczek M, Magdziak Z, Goliński P, Siwulski M, Stuper-Szablewska K (2013) Concentrations of minerals in selected edible mushroom species growing in Poland and their effect on human health. Acta Scient Poloniae, Technol Alim 12:203-214

Mleczek M, Magdziak Z, Gąsecka M, Niedzielski P, Kalač P, Siwulski M, Rzymski P, Zalicka S, Sobieralski K (2016a) Content of selected elements and low-molecular-weight organic acids in fruiting bodies of edible mushroom Boletus badius (Fr.) Fr. from unpolluted and polluted areas. Environ Sci Poll Res 23:20609-20618

Mleczek M, Niedzielski P, Kalač P, Budka M, Siwulski M, Gąsecka M, Rzymski P, Magdziak Z, Sobieralski K (2016b) Multielemental analysis of 20 mushroom species growing near a heavily trafficked road in Poland. Environ Sci Poll Res 23:16280-16295

Mleczek M, Siwulski M, Rzymski P, Niedzielski P, Gasecka M, Jasińska A, Budzyńska S, Budka A (2017) Multielemental analysis of Lentinula edodes mushrooms available in trade. J Environ Sci Health Part B 52:196-205

Ouzouni P, Riganakos K (2007) Nutritional value and metal content profile of Greek wild edible fungi. Acta Aliment 36:103-114

Řanda Z, Kučera J (2004) Trace elements in higher fungi (mushrooms) determined by activation analysis. J Radioanal Nucl Chem 259:99-107

Řanda Z, Soukal L, Mizera J (2005) Possibilities of the short-term thermal and epithermal neutron activation for analysis of macromycetes (mushrooms). J Radioanal Nucl Chem 264:67-76 
Rizal LM, Hyde KD, Chukeatirote E, Chamyuang S (2015) Proximate analysis and mineral constituents of Macrolepiota dolichaula and soils beneath its fruiting bodies. Mycosphere 6:414-420. doi:10. 5943/mycosphere/6/4/3

Saba M, Falandysz J, Nnorom IC (2016a) Accumulation and distribution of mercury in fruiting bodies by fungus Suillus luteus foraged in Poland, Belarus and Sweden. Environ Sci Poll Res 23:2749-2757

Saba M, Falandysz J, Nnorom IC (2016b) Mercury determination in Suillus bovinus mushroom: accumulation, distribution, probable dietary intake. Environ Sci Poll Res 23:14549-14559

Saba M, Falandysz J, Nnorom IC (2016c) Evaluation of vulnerability of Suillus variegatus and Suillus granulatus mushrooms' to sequester mercury in fruiting bodies. J Environ Sci Health Part B 51:640-545

Sarikurkcu C, Tepe B, Kocak MS, Uren MC (2015) Metal concentration and antioxidant activity of edible mushrooms from Turkey. Food Chem 175:549-555

Shi W, Feng X, Zhang G, Ming L, Yin R, Zhao Z, Wang J (2011) Highprecision measurement of mercury isotope ratios of atmospheric deposition over the past 150 years recorded in a peat core taken from Hongyuan, Sichuan Province, China. Chin Sci Bull 56:877-882

Širić I, Humar M, Kasap A, Kos I, Boro M, Pohleven F (2016) Heavy metal bioaccumulation by wild edible saprophytic and ectomycorrhizal mushrooms. Environ Sci Pollut Res 23:18239-18252

Statistical Office (2014) Forests in Poland, Belarus, Lithuania and Ukraine in 2010. Statistical Office, Białystok https:/www.google.pl/search? $\mathrm{q}=$ gatunki+drzewa $+\mathrm{w}+$ polsce $\& \mathrm{ie}=\mathrm{utf}-8 \&$ oe $=$ utf- $8 \&$ client $=$ firefox b\&gfe_rd=cr\&ei=GaLvWNGjIOOv8wf2g634Dw\#q=major+tree+ species+in+polish+forests\&start=10 (retrieved on April 13, 2017)
Stefanović V, Trifković J, Mutić J, Tešić Ž (2016a) Metal accumulation capacity of Parasol Mushroom (Macrolepiota procera) from Rasina region (Serbia). Environ Sci Poll Res 23:13178-13190

Stefanović V, Trifković J, Djurdjić S, Vukojević V, Tešić Ž, Mutić J (2016b) Study of silver, selenium and arsenic concentration in wild edible mushroom Macrolepiota procera, health benefit and risk. Environ Sci Poll Res 23:22084-22098

Steinhauser G, Steinhauser V (2016) A simple and rapid method for reducing radiocesium concentrations in wild mushrooms (Cantharellus and Boletus) in the course of cooking. J Food Prot 79:1995-1999

Tabouret H, Bareille G, Claverie F, Pécheyran C, Prouzet P, OF D (2010) Simultaneous use of strontium:calcium and barium:calcium ratios in otoliths as markers of habitat: application to the European eel (Anguilla anguilla) in the Adour basin, South West France. Mar Environ Res 70:35-45

Vetter J, Siller I (1997) Ásványi anyagok mennyiségének alakulása a gomba termőtestben (Macrolepiota procera). Mikolódiai Közlemények 36:33-39

Woźniak W (2009) Production and quality appraisal of mycelium of parasol mushroom Macrolepiota procera (Scop. ex Fr.) Sing. Herba Polonica 55:285-291

Wyrzykowska B, Szymczyk K, Ichihashi H, Falandysz J, Skwarzec B, Yamasaki S (2001) Application of ICP sector field MS and principal component analysis for studying interdependences among 23 trace elements in Polish beers. J Agric Food Chem 49:3425-3431

Xiaolan M (2009) Macromycetes of China <www.sciencep.com>, Beijing. ISBN978-7-03-024413-0 